\title{
Bilateral iliac artery aneurysm: A rare cause of postpartum recurrent hemorrhage
}

\section{Bilateral iliak arter anevrizmasi: Postpartum rekürren kanamanın nadir bir nedeni}

\author{
(1) Emsal Pınar Topdağı Yılmaz ${ }^{1}$, (1) Yunus Emre Topdağı ${ }^{2}$, (1) Suat Eren ${ }^{3}$, (1) Yakup Kumtepe ${ }^{1}$ \\ ${ }_{1}^{1}$ Atatürk University Faculty of Medicine, Department of Gynecology and Obstetrics, Erzurum, Turkey \\ 2 Sanko University Faculty of Medicine, Department of Gynecology and Obstetrics, Gazinatep, Turkey \\ ${ }^{3}$ Atatürk University Faculty of Medicine, Department of Radiology, Erzurum, Turkey
}

\begin{abstract}
Postpartum hemorrhage (PPH) is a critical health problem that may result in maternal death. In cases of impaired maternal hemodynamics, several surgical therapies such as hypogastric artery ligation or postpartum hysterectomy may be employed to control the bleeding. A 30-year-old multiparous patient who had given birth via spontaneous vaginal delivery had undergone hysterectomy and then hypogastric artery ligation due to postpartum hemorrhage. The patient was referred to our clinic due to uncontrolled bleeding and she experienced recurrent episodes of massive hemorrhage during her follow-up in our clinic. Pelvic angiography performed by interventional radiologists to detect the bleeding focus revealed arteriovenous fistula and aneurysm in the right internal iliac artery and incomplete ligation of the left internal iliac artery. The bleeding was controlled by selective embolization through coiling of the fistula in the right internal iliac artery and branches of the left uterine artery. PPH is still an important cause of maternal mortality and vascular structural anomalies must be borne in mind in cases with delayed onset.

Keywords: İliac artery aneurysm, postpartum hemorrhage, maternal mortality

$\ddot{\mathrm{O} z}$

Postpartum kanamalar, maternal ölüme neden olabilecek kritik bir să̆lık sorunudur. Bozulmuş maternal hemodinamik durumlarda, kanamayı kontrol etmek için hipogastrik arter ligasyonu veya postpartum histerektomi gibi çeşitli cerrahi tedaviler kullanılabilir. Otuz yaşındaki bir multipar spontan vajinal yolla doğum yapmış olan hasta histerektomi ve postpartum kanama nedeniyle hipogastrik arter ligasyonu geçirmişti. Hasta kontrolsüz kanama nedeniyle kliniğimize sevk edildi ve kliniğimizde takiplerinde tekrarlayan masif kanama atakları geçirdi. Girişimsel radyologlar tarafından kanama odağını saptamak için yapılan pelvik anjiyografide kanama odağını tespit etmek için sağ internal iliak arterde arteriyovenöz fistül ve anevrizma ve sol internal iliak arterin tam ligate olmadığı saptandı. Hastanın sağ iliak arter ve sol uterin arterine selektif embolizasyon yapılarak kanama control altına alındı. Postpartum kanamalar her türlü girişimsel işleme ragmen hala anne ölümlerinin önemli bir nedenidir.

Anahtar Kelimeler: İliak arter anevrizması, doğum sonrası kanama, anne ölümü
\end{abstract}

\section{Introduction}

Postpartum hemorrhage (PPH) is a serious health problem that may result in maternal death by causing an impairment of maternal hemodynamics ${ }^{(1,2)}$. According to the world health organization, approximately 150.000 women die annually of $\mathrm{PPH}^{(3,4)}$. Postpartum hysterectomy should be the last resort for surgeons due to its morbidity and effects on the patient's fertility. Alternatively, hypogastric artery ligation is a fertilitypreserving treatment that is associated with a low success rate and high levels of complication if not performed by experienced surgeons ${ }^{(1,5)}$. Pelvic arterial embolization is an alternative treatment for both hysterectomy and hypogastric artery ligation due to its effects on morbidity and patients' fertility. It continues to be a relevant procedure because it is a minimally invasive intervention ${ }^{(6,7)}$. The current report presents a patient with PPH who underwent embolization, in whom bleeding could not be controlled despite repeated surgical interventions, and in whom a bleeding focus that would explain this clinical condition could not be detected intraoperatively.

Address for Correspondence/Yazışma Adresi: Yunus Emre Topdağı, MD,

Sanko University School of Medicine, Department of Gynecology and Obstetrics, Gazinatep, Turkey

Phone: +90 5358234656 E-mail: emr-topdagi@hotmail.com ORCID ID: orcid.org/0000-0003-0656-0765

Received/Geliș Tarihi: 16.04.2019 Accepted/Kabul Tarihi: 06.02.2020

${ }^{\oplus}$ Copyright 2020 by Turkish Society of Obstetrics and Gynecology

Turkish Journal of Obstetrics and Gynecology published by Galenos Publishing House 


\section{Case report}

The 30-year-old, gravidity 3, parity 2 patient had no medical problems during her pregnancy follow-up visits, such as gestational diabetes, preeclampsia, intrauterine growth retardation, and premature delivery. The patient had given birth to a baby weighing 3500 grams via spontaneous vaginal delivery at 39 weeks of gestation and she experienced heavy bleeding at day 6 after birth. The patient did not respond to medical therapies and conventional methods and underwent hysterectomy due to impaired hemodynamics caused by uncontrolled bleeding. The patient was discharged on postoperative day 3 with full recovery. The patient experienced active vaginal bleeding on postoperative day 10 and underwent cuff repair through the vaginal route after exploration. Possible bleeding foci that were inspected during exploration were sutured and then the patient was discharged with full recovery. However, the patient experienced recurrent abundant bleeding on postoperative day 20 for which she was hospitalized and underwent bilateral hypogastric artery ligation. The patient experienced another episode of abundant bleeding on day 7 after the hypogastric artery ligation and she was then referred to our clinic. The patient's hemodynamics was stable on initial examination. Laboratory parameters were normal. Abdominal ultrasonography revealed normal ovaries and no fluid in the abdominal cavity. A vaginal examination revealed no bleeding. The patient experienced heavy bleeding on day 3 after admission to our clinic and she also had impairment in her hemodynamics. Her hemoglobin was $4.8 \mathrm{~g} / \mathrm{dL}$ and the patient was administered 4 units of erythrocyte suspension. The patient underwent emergency surgery, but no active bleeding focus was detected. A consultation with a radiologist was performed because no bleeding focus was detected intraoperatively, and the patient underwent computed tomography (CT) with contrast enhancement. The CT scans showed findings suggestive of aneurysmal filling in the pelvic area (Figure 1). The patient had ongoing bleeding and she underwent angiography in the interventional radiology clinic. Initial angiography revealed an arteriovenous fistula and aneurysm filling from the right internal iliac artery (Figure 2). The artery fistula was closed with a coil. The right internal iliac artery was totally obstructed by the coil, causing intermittent bleeding after partial intraoperative ligation. On the second day after the intervention, the patient still had bleeding, although the amount had decreased. The patient was re-evaluated by interventional radiologists; the branches of the left uterine artery were angiographically obstructed with microparticles and the partially-ligated left internal iliac artery was totally closed by coils (Figure 3). The patient received 15 units of erythrocyte suspension until the completion of the second procedure. The patient became hemodynamically stable following the procedure and had no recurrent bleeding during the follow-up period; she was discharged with full recovery on postoperative day 15 .

Informed consent was obtained from the patient.

\section{Discussion}

PPH is defined as $500 \mathrm{~mL}$ blood loss after normal delivery and $1000 \mathrm{~mL}$ blood loss after cesarean delivery. It is a significant health problem causing an impairment in maternal hemodynamics ${ }^{(1)}$. If there is no response to conservative therapies such as uterine massage and Bakri balloon placement, compression sutures, hypogastric artery ligation, hysterectomy, and pelvic arterial embolization can be employed ${ }^{(8,9)}$.

The pelvic organs are supplied by the internal iliac artery and ligation of this artery reduces bleeding by decreasing uterine arterial pressure ${ }^{(10,11)}$. Pelvic arterial embolization was used for the first time in 1979 for obstetric bleeding ${ }^{(7)}$. Selective arterial embolization offers a success rate ranging from $81 \%$ to $96 \%$ in different sources ${ }^{(12)}$. Pelvic arterial embolization is considered a safe procedure because it is a fertility-preserving minimally invasive procedure and, in experienced hands, it is also associated with reduced morbidity ${ }^{(1)}$. However, there are also publications reporting necrosis of the uterus, sciatic nerve, and bladder if not performed under the appropriate conditions ${ }^{(13,14)}$. Although uterine atony is the most common cause of PPH, vascular pathologies such as arteriovenous malformation (AVM), hemangioma, and vascular tumors must be borne in mind for patients with massive hemorrhage ${ }^{(15)}$. Variations in the pelvic vascular anatomy in particular may cause serious bleeding in the postpartum period. Selective arterial embolization performed after angiography is a safe and effective option in uncontrolled uterine bleeding ${ }^{(2)}$. There are reported cases in the literature in which selective pelvic embolization was performed due to PPH of different etiologies. Yu et al. ${ }^{(15)}$ reported the efficacy of selective arterial embolization in a patient with vaginal hemangioma who remained undetected in antenatal follow-up and who experienced massive bleeding after vaginal delivery with episiotomy. The development of collateral vessels between the inferior mesenteric artery (IMA) and uterus is not



Figure 1. Computed tomography images acquired in the arterial phase show enlarged vascular structured connected to the arteriovenous fistula (arrow head) and aneurysm sac (white arrow) 


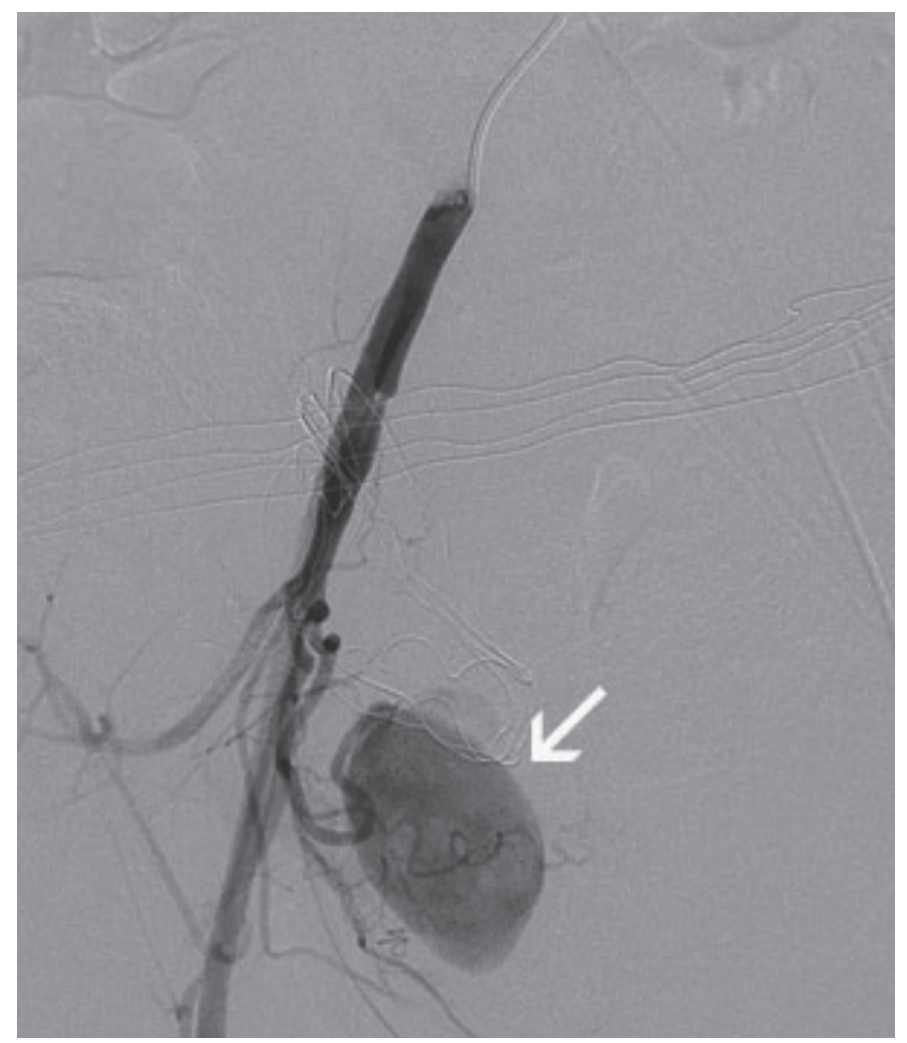

Figure 2. Right internal iliac artery angiography shows aneurysm sac



Figure 3. Embolization of the artery supplying the aneurysm with detachable coil (white arrow) and embolization of the internal iliac artery with pushable coil (arrow head) normally observed. However, it has been reported in patients with uterine fibroids and adenomyosis and those with a history of pelvic surgery, uterine artery ligation or embolization ${ }^{(16)}$. Shin et al. ${ }^{(2)}$ detected widespread collateral vessels between the IMA and uterine and ovarian arteries during angiography in a patient with massive PPH who had no history of uterine fibroids, pelvic surgery or embolization. They reported that the hemorrhage was controlled by the selective embolization of the distal branches of the IMA. Kim et al. ${ }^{(17)}$ reported a patient with massive PPH due to damage of the collateral network between the superior rectal branch of the IMA and the vaginal artery following vaginal delivery and they controlled the hemorrhage with embolization.

Vascular pathologies must be considered in patients with PPH with a delayed onset. In a series of 33 patients with PPH reported by Crespo et al. ${ }^{(1)}$, six patients experienced hemorrhage due to laceration of the uterine pseudoaneurysm and three patients had laceration of the branches of the vaginal, cervicovaginal and epigastric artery, and they reported the efficacy of selective embolization. In a study by Ganguli et al. ${ }^{(18)}$ reporting on 66 patients with PPH, a 95\% success rate was reported for uterine artery embolization and the rate of complication was reported as $4.5 \%$.

The most common causes of pseudoaneurysms occurring in the uterine artery are curettage, vaginal delivery, and genital infections ${ }^{(19)}$. In the study by Kiyokawa et al. ${ }^{(20)}$ that included six patients with cesarean scar pregnancy and uterine AVM or pseudoaneurysm, five patients underwent uterine artery embolization. Only one patient who underwent embolization resulted in hysterectomy.

The present case had intermittent hemorrhage but it was severe enough to impair hemodynamics after spontaneous vaginal delivery. A total of three operations were performed for vaginal cuff repair, hysterectomy, and finally hypogastric artery ligation because the bleeding focus could not be detected despite ongoing hemorrhage. The presence of recurrent hemorrhage and failure to detect the bleeding focus despite all plausible surgical interventions led us to consider the patient for vascular pathologies. The failure to control bleeding, after the detection of and intervention to the vascular pathology in the right side, raised the possibility of another pathology in the left side. We therefore emphasize the importance of bearing vascular pathologies in mind in patients with uncontrolled hemorrhage despite optimal surgical interventions. Consistent with the literature, we observed the successful embolization of the aneurysm accompanying the arteriovenous fistula and arterial branches causing bleeding due to incomplete suturing.

In conclusion, emergency intervention in PPH can be lifesaving. Selective arterial embolization, which is less invasive and is associated with low complication rates, appears to be an appropriate option for patients unresponsive to conservative therapy. 


\section{Ethics}

Informed Consent: Informed consent was obtained from the patient.

Peer-review: Externally peer-reviewed.

\section{Authorship Contributions}

Surgical and Medical Practices: E.P.T.Y., Y.K., S.E., Concept: E.P.T.Y., Y.E.T., Design: E.P.T.Y., Y.E.T., Data Collection or Processing: E.P.T.Y., Y.E.T., Analysis or Interpretation: E.P.T.Y, Y.K., S.E., Literature Search: Y.E.T., Y.K., S.E., Writing: E.P.T.Y., Y.E.T.

Conflict of Interest: The authors declare no conflict of interest. Financial Disclosure: The authors declared that this study received no financial support.

\section{References}

1. Aguilar-Crespo A, Morales-Roselló J, Sánchez-Ajenjo C, Valle-Tejero A, García-Marcos R, Perales-Marín A. Postpartum hemorrhage with pelvic arterial embolization, study of 33 cases. J Matern Fetal Neonatal Med. 2017;16:1-6.

2. Shin SM, Yi KW, Chung HH. Postpartum Uterine Bleeding from the Inferior Mesenteric Artery: Case Report and Review of the Literature. Gynecol Obstet Invest 2015;80:60-3.

3. Ojengbede OA, Morhason-Bello IO, Galadanci H, Meyer C, Nsima $\mathrm{D}$, Camlin $\mathrm{C}$, et al. Assessing the role of the non-pneumatic antishock garment in reducing mortality from postpartum hemorrhage in Nigeria. Gynecol Obstet Invest 2011;71:66-72.

4. Thakur M, Adekola HO, Asaad R, Gonik B. Secondary Postpartum Hemorrhage due to Spontaneous Uterine Artery Rupture after Normal Vaginal Delivery Managed by Selective Arterial Embolization. AJP Rep 2016;6:442-4

5. Negura A. Indications for bilateral ligation of the uterine arteries and the hypogastric arteries in refractory obstetrical hemorrhages. Rev Fr Gynecol Obstet 1991;86:495-7.

6. Evans S, McShane P. The efficacy of internal iliac artery ligation in obstetric hemorrhage. Surg Gynecol Obstet 1985;160:250-3.

7. Brown BJ, Heaston DK, Poulson AM, Gabert HA, Mineau DE, Miller FJ Jr. Uncontrollable postpartum bleeding: a new approach to hemostasis through angiographic arterial embolization. Obstet Gynecol 1979;54:361-5.

8. Holub Z, Pertl J, Vorácek J. The surgical technic of ligation of the hypogastric artery. Cesk Gynekol 1988;53:763-5.
9. Ferguson JE, Bourgeois FJ, Underwood PB. B-Lynch suture for postpartum hemorrhage. Obstet Gynecol 2000;95:1020-2.

10. Torreblanca Neve E, Merchan Escalante G, Walter Tordecillas MA, Acosta Alfaro MA. Ligation of the hypogastric arteries. Analysis of 4000 cases. Ginecol Obstet Mex 1993;61:242-6.

11. Fătu C, Frâncu D, Puişor M, Fătu CI. Changes in the arterial pressure after ligation of the hypogastric artery. Rev Med Chir Soc Med Nat Iasi 1996;100:149-50.

12. Deux JF, Bazot M, Le Blanche AF, Tassart M, Khalil A, Berkane N, et al. Is selective embolization of uterine arteries a safe alternative to hysterectomy in patients with postpartum hemorrhage? AJR Am J Roentgenol 2001;177:145-9.

13. Al-Thunyan A, Al-Meshal O, Al-Hussainan H, Al-Qahtani MH, El-Sayed AA, Al-Qattan MM. Buttock necrosis and paraplegia after bilateral internal iliac artery embolization for postpartum hemorrhage. Obstet Gynecol 2012;120:468-70.

14. Palacios-Jaraquemada JM. Buttock necrosis and paraplegia after bilateral internal iliac artery embolization for postpartum hemorrhage. Obstet Gynecol 2012;120:1210.

15. Yu BR, Lee GE, Cho DH, Jeong YJ, Lee JH. Genital tract cavernous hemangioma as a rare cause of postpartum hemorrhage. Obstet Gynecol Sci 2017;60:473-76.

16. Dixon S, Tapping CR, Chuah PS, Bratby M, Uberoi R, Anthony S. Successful fibroid embolization of pelvic and inferior mesenteric artery collaterals after previous uterine artery embolization. Acta Radiol 2012;53:292-5.

17. Kim CH, Jeon GS, Lee SJ, Kang SH. Embolization of the inferior mesenteric artery for post-partum hemorrhage with a vaginal laceration: A case with unusual collateral supply. J Obstet Gynaecol Res 2016;42:1878-80.

18. Ganguli S, Stecker MS, Pyne D, Baum RA, Fan CM. Uterine artery embolization in the treatment of postpartum uterine hemorrhage. J Vasc Interv Radiol 2011;22:169-76.

19. Chou MM, Hwang JI, Tseng JJ, Huang YF, Ho ES. Cesarean scar pregnancy: quantitative assessment of uterine neovascularization with 3-dimensional color power Doppler imaging and successful treatment with uterine artery embolization. Am J Obstet Gynecol 2004;190:866-8.

20. Kiyokawa S, Chiyoda T, Ueno K, Saotome K, Kim SH, Nakada S. Development of pseudoaneurysm in cesarean section scar pregnancy: a case report and literature review. J Med Ultrason 2018;45:357-62. 